\title{
ANALISIS DAMPAK LALU LINTAS DITINJAU DARI TARIKAN PERJALANAN PADA KAWASAN RSUD KABUPATEN PANGKEP
}

\author{
St Maryam H${ }^{1}$, Lambang Basri Said², Tjahayadi ${ }^{3}$ \\ ${ }^{1}$ Dosen Jurusan Teknik Sipil Universitas Muslim Indonesia (UMI) \\ Jalan Urip Sumoharjo No.225 Makassar, Telp. 454534 \\ ${ }^{2}$ Dosen Jurusan Teknik Sipil Universitas Muslim Indonesia (UMI) \\ Jalan Urip Sumoharjo No.225 Makassar, Telp. 454534 \\ ${ }^{3}$ Mahasiswa Magister Teknik Sipil Universitas Muslim Indonesia (UMI) \\ Jalan Urip Sumoharjo No.225 Makassar,Telp.454534,Email : cahayadi1972@gmail.com
}

\begin{abstract}
Abstrak
Zona zona aktivitas berkedudukan sebagai zona penarik perjalanan. Salah satu zona aktifitas tersebut adalah Rumah Sakit. Rumah Sakit Umum Daerah Kabupaten Pangkep yang terletak di pusat kota Kabupaten Pangkep memiliki intensitas kegiatan yang cukup tinggi. Interaksi yang terjadi akibat dari kebutuhan akan kesehatan baik itu pasien dan keluarga atau para pembesuk juga para petugas medis atau pengelola rumah sakit dan lainnya tersebut akan menghasilkan pergerakan arus lalu lintas di sekitar komplek Rumah Sakit yang akan menimbulkan permasalahan diantaranya terjadinya peningkatan volume lalu lintas pada ruas jalan yang berada di sekitar Rumah Sakit Umum Daerah Pangkep. Penelitian ini bertujuan untuk mengetahui berapa banyak tarikan yang terjadi pada Rumah Sakit Umum Daerah Pangkep, mencari kontribusi pembagian lalu lintas yang terjadi pada ruas jalan disekitar Rumah Sakit Umum Daerah Pangkep serta kapasitas jalan yang terbebani pengunjung Rumah Sakit Umum Daerah Pangkep. pada penelitian ini dilakukan metode survei dengan kuisioner untuk mengetahui karakteristik sosial ekonomi. Teknik pengambilan sampel dilakukan dengan cara random secara proporsional untuk setiap pengunjung yang menggunakan moda tertentu untuk mencapai Rumah Sakit Umum Daerah Pangkep yang mewakili semua zona. Berdasarkan hasil analisis, Prediksi untuk 10 tahun kedepan akan terjadi peningkatan intensitas kegiatan di Rumah Sakit Umum Daerah Pangkep, pada tahun 2019 Rumah Sakit Umum Daerah Pangkep dengan luas bangunan $\pm 10.885 \mathrm{~m} 2$ tersebut mampu menarik sebanyak 172 mobil per hari dan 581 sepeda motor per hari, serta menarik pengunjung sebanyak 1207 orang per hari, pada 10 tahun kedepan Rumah Sakit Umum Daerah Pangkep akan menarik sebanyak 206 mobil per hari dan 697 sepeda motor per hari, serta menarik pengunjung sebesar 1447 orang per hari. Kinerja ruas jalan sudah hampir mencapai batas atas aman ditunjukan dengan DS yang sudah mencapai 0,31 pada tahun 2019 dan DS akan bertambah menjadi 0,45 pada tahun 2029 .
\end{abstract}

Kata Kunci : Tarikan Perjalanan, Prediksi 10 tahun ke depan, Kinerja ruas jalan

\section{PENDAHULUAN}

\subsection{Latar Belakang}

Kota Pangkaje'ne sebagai ibukota di daerah kabupaten Pangkep adalah kota yang mempunyai perkembangan dengan tingkat pertumbuhan cukup pesat, dengan jumlah penduduk 335.514 jiwa, oleh karena itu maka pemerintah harus menyediakan sarana dan prasarana kota untuk menunjang kelancaran dari pertumbuhan kota Pangkaje'ne itu sendiri. Dalam hal perkembangan kota yang cukup menonjol dan pesat perkembangannya adalah tempat pelayanan kesehatan. 
Banyaknya fasilitas kesehatan yang ditawarkan oleh Rumah Sakit dan baik buruknya pelayanan yang diberikan sangat berpengaruh terhadap jumlah pasien yang akan berobat di Rumah Sakit tersebut. Rumah Sakit Umum Daerah Pangkep adalah pusat pelayanan kesehatan di kabupaten Pangkep, seluruh unsur pelayanan kesehatan yang ada di kecamatan yaitu: Puskesmas, Pustu, Polindes dan juga klinik dalam hal pelayanan mengalami keterbatasan fasilitas dan tenaga ahli atau dokter spesialis maka pasien akan dirujuk ke Rumah Sakit Umum Pangkep. Hal tersebut akan menimbulkan tarikan dan bangkitan lalu lintas pada jalan-jalan disekitar Rumah Sakit Umum Pangkep dan akan menambah volume lalu lintas.

Meskipun bukan satu-satunya penyebab utama penurunan kinerja jalan, terjadinya penambahan volume lalu lintas jalan akan mengakibatkan kemacetan lalu lintas pada ruas jalan disekitar pusat pelayanan kesehatan tersebut. Hal ini sering diakibatkan oleh perilaku manusia yang kurang mematuhi rambu-rambu lalulintas. Hal lain yang mempengaruhi kemacetan lalu lintas disebabkan pula oleh adanya pergerakan kendaraan keluar masuk tempat perbelanjaan disekitar Rumah Sakit dan aktifitas Kantor Dinas Kesehatan yang bersebelahan dengan kawasan Rumah Sakit. Keadaan tersebut masih pula diperparah dengan adanya angkutan umum yang berhenti menunggu penumpang menambah pula kesemrawutan jalan sekitar Rumah Sakit.

Dari kondisi tersebut maka sudah seharusnya pemerintah daerah kabupaten Pangkaje'ne dan Kepulauan mewajibkan membuat Analisis Dampak Lalu lintas untuk setiap pusat aktifitas/ kegiatan berskala besar yang mempunyai andil besar dalam penambahan pembebanan kapasitas jalan, karena dengan dibuat Analisis Dampak Lalu lintas maka diharapkan gangguan lalu lintas dapat segera di ketahui sedini mungkin untuk selanjutnya digunakan sebagai bahan evaluasi kinerja jalan sekitar pusat kegiatan dan dapat memberikan solusi terbaik untuk mengatasi permasalahan lalu lintas pada daerah tersebut.

\subsection{Rumusan Masalah}

Pembangunan Rumah Sakit Umum Kabupaten Pangkep tidak didahului dengan pembuatan Analisis Dampak Lalu lintas sehingga pada saat beroperasinya Rumah Sakit menimbulkan kekhawatiran akan munculnya permasalahan lalu lintas di ruas jalan yang berada disekitar kawasan Rumah Sakit tersebut yaitu;

1. Bagaimana memperkirakan timbulnya tarikan perjalanan yang disebabkan karena Rumah Sakit Umum Pangkep merupakan pusat pelayanan kesehatan. Jadi perlu diketahui tarikan perjalanan pada kondisi eksisting.

2. Bagaimana kinerja dari ruas jalan Mawar sebagai dampak aktivitas Rumah Sakit. Dampak tersebut berupa meningkatnya kepadatan lalu lintas dan menurunnya kecepatan jalan itu sendiri dan pada akhirnya akan menimbulkan masalah kemacetan.

3. Dengan meningkatnya aktivitas di jalan Mawar maka akan memberikan potensi untuk menjadi penyebab terjadinya kecelakaan lalu lintas antara kendaraan yang akan parkir dibahu jalan dengan kendaraan yang melaju lurus maupun kendaraan yang keluar dari tempat-tempat perbelanjaan yang ada disekitar jalan Mawar tersebut, jadi sangat perlu dirumuskan bagaimana alternatif penanganan untuk mengurangi masalah lalu lintas yang terjadi.

\subsection{Tujuan Penelitian}

Dari kondisi di atas maka ada beberapa permasalahan yang menarik yang ingin dibahas dan diteliti untuk perkembangan lalu lintas dimasa yang akan datang dengan tujuan untuk :

1. Memprediksi tarikan perjalanan yang terjadi akibat adanya aktifitas pelayanan kesehatan pada Rumah Sakit

2. Mengukur kinerja lalu lintas pada ruas jalan yang diperkirakan terpengaruh oleh adanya pusat kegiatan pelayanan kesehatan. 
3. Merumuskan alternatif penanganan yang mungkin dilakukan untuk mengurangi masalah lalu lintas yang terjadi di jalan sekitar Rumah Sakit.

\section{METODOLOGI PENELITIAN}

\subsection{Kebutuhan Data Penelitian}

Data primer didapat dengan melaksanakan survei langsung di lapangan yang meliputi :

1. Survei wawancara/ kuesioner pengunjung Rumah Sakit, ini dilaksanakan untuk data asal pengunjung, tujuan pengunjung, pendapatan pengunjung dan lain-lain. Survei ini berguna untuk mengetahui tarikan dan penyebaran perjalanan oleh pengunjung Rumah Sakit.

2. Inventarisasi tata guna lahan, inventarisasi ini dilakukan untuk melihat peruntukan dan potensi penggunaan lahan yang ada disekitar kawasan Jalan Mawar yang memberikan pengaruh terhadap bangkitan dan tarikan perjalanan yang ada dan akan membebani jalan.

3. Survei jaringan jalan, survei yang dilakukan adalah melakukan identifikasi terhadap pola jaringan yang ada di sekitar Jalan Sultan Hasanuddin dan Jalan Mawar, dimensi ruas jalan dan LHR.

4. Survei hambatan samping yang diakibatkan oleh kendaraan keluar masuk RSUD Pangkep.

5. Survei manajemen lalu lintas kondisi eksisting, yang terdiri dari :

a. Survei volume lalu lintas ruas jalan, survei yang dilakukan adalah menghitung volume lalu lintas kendaraan secara terklasifikasi, yang lewat pada ruas jalan.

b. Survei kecepatan perjalanan sesaat, survei ini melakukan pengukuran kecepatan perjalanan sesaat sampel beberapa kendaraan yang lewat pada titik pengamatan.

Data-data sekunder didapat dari penelitian-penelitian terdahulu dan dari instansiinstansi terkait yang meliputi :

1. Data kondisi sosial ekonomi dan Rencana Umum Tata Ruang Kota (RUTRK), data ini berguna untuk mengetahui tingkat sosial ekonomi masyarakat sekitar lokasi penelitian serta rencana pengembangan ekonomi kawasan sekitarnya, data ini didapat dari Badan Pusat Statistik dan Bappeda Kabupaten Pangkep.

2. Data kepemilikan kendaraan dan Data tingkat pertumbuhan lalu lintas sangat berguna untuk memprediksi pertumbuhan lalu lintas yang akan datang, data ini didapat dari Dinas Perhubungan Kabupaten Pangkep.

3. Tingkat pendapatan perkapita kabupaten Pangkep yang didapat dari Bappeda Kabupaten Pangkep.

4. Data jumlah pengunjung Rumah Sakit yang didapatkan dari pengelola Rumah Sakit Umum Daerah Kabupaten Pangkep.

5. Data tentang luas bangunan utama dan bangunan parkir yang didapatkan dari pengelola Rumah Sakit Umum Daerah Kaupaten Pangkep.

\subsection{Tahapan Analisis}

\section{Analisis tarikan lalu lintas}

Memperkirakan tarikan lalu-lintas akibat aktifitas Rumah Sakit yang akan memberi tambahan beban terhadap jaringan jalan di kawasan JaIan Mawar. Hal-haI yang dilakukan adalah :

a. Menganalisis tarikan lalu lintas Rumah Sakit.

b. Menganalisis sistem jaringan jalan yang terkait dengan prediksi 10 tahun mendatang.

2. Analisis kinerja ruas jalan

Analisis yang dilakukan adalah menghitung beberapa parameter yang mempengaruhi kinerja ruas, seperti : derajat kejenuhan, kecepatan. Metode yang digunakan adalah MKJI, 
1997. Hasil perhitungan dengan MKJI ini kemudian dikalibrasi untuk mendapatkan hasil perhitungan yang mendekati kondisi yang sesuai dengan keadaan di lapangan.

\section{ANALISIS DATA}

\subsection{Analisa Kapasitas Jalan}

Untuk menganalisis tingkat Volume lalu lintas adalah jumlah kendaraan yang melewati ruas jalan tertentu dalam satuan waktu. Perhitungan volume dilakukan perjam untuk satu atau lebih periode, misalnya didasarkan pada kondisi arus lalu lintas rencana jam puncak pada pagi, siang atau sore. Adapun data data yang dapat diambil adalah arus lalu lintas total, jumlah kendaraan (LV,HV,MC) total pada jam puncak. pelayanan jalan maka perlu dilakukan perhitungan derajat kejenuhan dimana derajat kejenuhan merupakan perbandingan antara jumlah lalu lintas yang melewati ruas jalan total dua arah dengan kapasitas total ruas jalan yang ditinjau. Dengan melihat data dan Tabel 4.33 didapatkan data mengenai jumlah volume total dan kapasitas total.

1. Jalan Sultan Hasanuddin

Diketahui pada hari libur Qtot adalah 1.525,55 SMP/ Jam sedangkan kapasitas jalannya adalah 5.645,38 SMP/ Jam sehingga DS-nya adalah 0,27. Untuk hari kerja Qtot adalah 1.740,03 SMP/ Jam sedangkan kapasitas jalannya adalah 5.645,38 SMP/Jam sehingga DS-nya adalah 0,31

2. Jalan Mawar

Diketahui pada hari libur Qtot adalah 267,31 SMP/ Jam sedangkan kapasitas jalannya 1.952,8 SMP/ Jam adalah sehingga DS-nya adalah 0,14. Untuk hari kerja Qtot adalah 709,5 SMP/ Jam sedangkan kapasitas jalannya 1.952,8 SMP /Jam adalah sehingga DS-nya adalah 0,36 .

Dari perhitungan data diatas dapat dilakukan analisis tingkat pelayanan jalan dengan menggolongkan perbandingan volume kendaraan pada ruas jalan tersebut dengan kapasitas jalan tersebut ke dalam tabel penggolongan tingkat pelayanan jalan yang dapat dilihat pada Tabel 1. Penggolongan ini ditabelkan seperti yang terlihat dibawah ini :

Tabel 1. Penggolongan Tingkat Pelayanan Jalan

\begin{tabular}{|c|l|c|c|l|}
\hline Waktu & \multicolumn{1}{|c|}{ Nama } & Qtot/V & $\begin{array}{c}\text { Tingkat } \\
\text { Pelayanan }\end{array}$ & \multicolumn{1}{|c|}{ Uraian } \\
\hline $\begin{array}{l}\text { Libur } \\
\text { Kerja }\end{array}$ & $\begin{array}{l}\text { Sultan Hasanuddin } \\
\text { Sultan Hasanuddin }\end{array}$ & 0,27 & $\begin{array}{l}\text { B } \\
\text { B }\end{array}$ & $\begin{array}{l}\text { Arus stabil, kecepatan operasi } \\
\text { mulai terbatasi sedikit atau sama } \\
\text { sekalidak mengalami } \\
\text { keterbatasan dalam kemampuan } \\
\text { bergerak akibat kendaraan lain. }\end{array}$ \\
\hline Libur & Mawar & 0,14 & A & $\begin{array}{l}\text { Arus bebas, volume rendah dan } \\
\text { kecepatan tinggi, pengemudi } \\
\text { dapat memilih kecepatan } \\
\text { dikehendaki }\end{array}$ \\
Mawar & 0,36 & B & $\begin{array}{l}\text { Arus stabil, kecepatan operasi } \\
\text { mulai terbatasi sedikit atau sama } \\
\text { sekali tidak mengalami } \\
\text { keterbatasan dalam kemampuan } \\
\text { bergerak akibat kendaraan lain. }\end{array}$ \\
\hline
\end{tabular}

Sumber : Hasil analisis 2019

Dari Tabel di atas dapat dijelaskan bahwa kondisi lalu-lintas pada Jalan Sultan Hasanuddin dan Jalan Mawar tidak terlalu mengalami permasalahan. 


\subsection{Analisis Prediksi Arus Lalu-lintas untuk 10 Tahun Mendatang}

Dari data arus lalu-lintas yang telah diperoleh dan ditunjukkan pada Tabel 4.33 dapat dihitung perkiraan jumlah arus kendaraan untuk periode sepuluh tahun mendatang. Analisis ini berguna untuk mengetahui apakah kapasitas jalan yang ada sekarang ini dapat menampung arus kendaraan yang diprediksikan melewati jalan yang ditinjau pada tahuntahun mendatang. Adapun persamaan untuk menentukan perkiraan arus lalu lintas yang akan terjadi pada tahun-tahun berikutnya adalah sebagai berikut:

Keterangan :

$$
P=P o(1+i)^{n}
$$

$\mathrm{P}=$ Jumlah kendaraan pada tahun ke-n

Po $=$ Jumlah kendaraan pada tahun awal

$\mathrm{i}=$ Tingkat pertumbuhan kendaraan

$\mathrm{n}=$ Waktu (tahun)

Setelah data arus arus lintas pada tahun 2019 diketahui, kemudian dilakukan prediksi arus lalu-lintas yang akan terjadi pada 10 tahun mendatang. Dari Rencana Umum Tata Kota (RUTK) diketahui bahwa tingkat pertumbuhan kendaraan rata-rata di Kabupaten Pangkep adalah sebesar 3,8\%. Setelah data arus lalu lintas untuk 10 tahun mendatang didapat kemudian dibandingkan dengan kapasitas jalan yang ada sehingga didapatkan derajat kejenuhan. Dari derajat kejenuhan ini dapat dikategorikan apakah kapasitas jalan tersebut masih memenuhi. Untuk lebih jelasnya dapat dilihat pada tabel berikut ini :

Tabel 2 Prediksi Arus Lalu lintas Jalan Sultan Hasanuddin Pada Hari Libur

\begin{tabular}{|c|c|c|c|}
\hline TAHUN & ARUS LALIN & KAPASITAS & DS \\
\hline 2019 & 1525,55 & 5645,38 & 0,27 \\
\hline 2020 & 1583,52 & 5645,38 & 0,28 \\
\hline 2021 & 1643,7 & 5645,38 & 0,29 \\
\hline 2022 & 1706,16 & 5645,38 & 0,30 \\
\hline 2023 & 1770,99 & 5645,38 & 0,31 \\
\hline 2024 & 1838,29 & 5645,38 & 0,33 \\
\hline 2025 & 1908,14 & 5645,38 & 0,34 \\
\hline 2026 & 1980,65 & 5645,38 & 0,35 \\
\hline 2027 & 2055,92 & 5645,38 & 0,36 \\
\hline 2028 & 2134,04 & 5645,38 & 0,38 \\
\hline 2029 & 2215,13 & 5645,38 & 0,39 \\
\hline
\end{tabular}

Sumber : Hasil Analisis 2019

Tabel 3 Prediksi Arus Lalu-lintas Jalan Sultan Hasanuddin Pada Hari Kerja

\begin{tabular}{|c|c|c|c|}
\hline TAHUN & ARUS LALIN & KAPASITAS & DS \\
\hline 2019 & 1740,03 & 5645,38 & 0,31 \\
\hline 2020 & 1806,15 & 5645,38 & 0,32 \\
\hline 2021 & 1874,79 & 5645,38 & 0,33 \\
\hline 2022 & 1946,03 & 5645,38 & 0,34 \\
\hline 2023 & 2019,98 & 5645,38 & 0,36 \\
\hline 2024 & 2096,74 & 5645,38 & 0,37 \\
\hline 2025 & 2176,41 & 5645,38 & 0,39 \\
\hline 2026 & 2259,11 & 5645,38 & 0,40 \\
\hline 2027 & 2344,96 & 5645,38 & 0,41 \\
\hline 2028 & 2434,07 & 5645,38 & 0,43 \\
\hline 2029 & 2526,56 & 5645,38 & 0,45 \\
\hline
\end{tabular}

Sumber : Hasil Analisis 2019 
Dari Tabel di atas dapat dilihat prediksi arus lalu lintas pada hari libur di tahun 2029 derajat kejenuhan 0,39 yaitu masuk pada tingkat pelayanan B dimana dengan karakter arus stabil, kecepatan operasi mulai terbatasi sedikit atau sama sekali tidak mengalami keterbatasan dalam kemampuan bergerak akibat kendaraan lain, sedangkan pada hari kerja ditahun 2029 derajat kejenuhan 0,45 yang mana sudah memasuki tingkat pelayanan C dengan karakter arus masih stabil namun kecepatan dan kemampuan bergerak semakin terbatas.

Tinjauan berikutnya adalah Jalan Mawar yang berada pada samping RSUD. Arus lalu lintas yang melewati jalan ini tidak terlalu padat seperti halnya pada Jalan Sultan Hasanuddin, dalam penelitian ini juga dilakukan analisis prediksi arus lalu lintas pada Jalan Mawar. Berikut ini tabel mengenai prediksi arus lalu lintas yang terjadi pada 10 (sepuluh) tahun mendatang dan dibandingkan dengan kapasitas jalan yang ada, apakah untuk 10 (Sepuluh) tahun mendatang kapasitas Jalan Mawar masih mampu menampung arus lalu lintas yang melintas.

Tabel 4 Prediksi Arus Lalu-lintas Jalan Mawar Pada hari libur

\begin{tabular}{|c|c|c|c|}
\hline TAHUN & ARUS LALIN & KAPASITAS & DS \\
\hline 2019 & 267,31 & 1952,8 & 0.14 \\
\hline 2020 & 277,47 & 1952,8 & 0,14 \\
\hline 2021 & 288,01 & 1952,8 & 0,15 \\
\hline 2022 & 298,96 & 1952,8 & 0,15 \\
\hline 2023 & 310,32 & 1952,8 & 0,16 \\
\hline 2024 & 322,11 & 1952,8 & 0,16 \\
\hline 2025 & 334,35 & 1952,8 & 0,17 \\
\hline 2026 & 347,05 & 1952,8 & 0,18 \\
\hline 2027 & 360,24 & 1952,8 & 0,18 \\
\hline 2028 & 373,93 & 1952,8 & 0,19 \\
\hline 2029 & 388,14 & 1952,8 & 0,20 \\
\hline
\end{tabular}

Sumber : Hasil Analisis 2019

Tabel 5 Prediksi Arus Lalu-lintas Jalan Mawar Pada Hari Kerja

\begin{tabular}{|c|c|c|c|}
\hline TAHUN & ARUS LALIN & KAPASITAS & DS \\
\hline 1 & 2 & 3 & 4 \\
\hline 2019 & 709,5 & 1952,8 & 0,36 \\
\hline 2020 & 736,46 & 1952,8 & 0,38 \\
\hline 2021 & 764,45 & 1952,8 & 0,39 \\
\hline 2022 & 793,5 & 1952,8 & 0,41 \\
\hline 2023 & 823,65 & 1952,8 & 0,42 \\
\hline 2024 & 854,95 & 1952,8 & 0,44 \\
\hline 2025 & 887,43 & 1952,8 & 0,45 \\
\hline 2026 & 921,16 & 1952,8 & 0,47 \\
\hline 2027 & 956,16 & 1952,8 & 0,49 \\
\hline 2028 & 992,5 & 1952,8 & 0,51 \\
\hline 2029 & 1030,21 & 1952,8 & 0,53 \\
\hline
\end{tabular}

Sumber : Hasil Analisis 2019

Dari Tabel di atas dapat dilihat prediksi arus lalu lintas pada hari libur di tahun 2029 derajat kejenuhan 0,20 yaitu masuk pada tingkat pelayanan B dimana dengan karakter arus stabil, kecepatan operasi mulai terbatasi sedikit atau sama sekali tidak mengalami 
keterbatasan dalam kemampuan bergerak akibat kendaraan lain, sedangkan pada hari kerja ditahun 2029 derajat kejenuhan 0,53 yang mana sudah memasuki tingkat pelayanan C dengan karakter arus masih stabil namun kecepatan dan kemampuan bergerak semakin terbatas.

Pada analisis dampak lalu lintas yang dilakukan ini mempunyai nilai yang relatif kecil sehingga pada pelaksanaannya pengoperasian RSUD Pangkep mempunyai pengaruh yang kecil terhadap lalu lintas disekitar RSUD Pangkep.

\section{KESIMPULAN}

Berdasarkan atas pendataan dan analisis data yang telah dilakukan maka dapat diambil beberapa kesimpulan yaitu sebagai berikut :

1. Untuk memperkirakan berapa besar tarikan perjalanan yang ditimbulkan akibat adanya RSUD Pangkep yaitu dengan:

a. Mengetahui karakteristik pengunjung RSUD, diketahui asal pengunjung dan moda yang dipakai serta tujuan pengunjung,

b. Memprediksi moda yang digunakan, diketahui prosentase dari setiap jenis kendaraan yang digunakan pengunjung,

c. Memprediksi penyebaran perjalanan, diketahui perkiraan proporsi penyebaran asal dan tujuan perjalanan pengunjung RSUD,

d. Memprediksi pembagian lalu lintas perjalanan, diketahui volume pergerakan kendaraan hasil pembagian lalu lintas.

Dari proses diatas diperoleh hasil yaitu, pada hari kerja;

a. Jalan Mawar dengan akses pintu samping RSUD total pengunjung 84,33 SMP/ jam dengan kapasitas jalan Mawar 709,5 SMP/ jam, diperoleh pembebanan arus lalu lintas pada jalan Mawar sebesar 11,88\% dari total volume lalu lintas,

b. Jalan Sultan Hasanuddin dengan akses pintu utama RSUD total pengunjung 162,81 SMP/ jam dengan kapasitas jalan Sultan Hasanuddin 1.740,03 SMP/ jam, diperoleh pembebanan arus lalu lintas pada jalan Sultan Hasanuddin sebesar 9,36\% dari total volume lalu lintas.

Pada hari libur dengan hasil yaitu;

a. Jalan Mawar dengan akses pintu samping RSUD total pengunjung 53,93 SMP/ jam dengan kapasitas jalan Mawar 267,3 SMP/ jam, diperoleh pembebanan arus lalu lintas pada jalan Mawar sebesar 20,18\% dari total volume lalu lintas,

b. Jalan Sultan Hasanuddin dengan akses pintu utama RSUD total pengunjung 62,38 SMP/ jam dengan kapasitas jalan Sultan Hasanuddin 1.525,54 SMP/ jam, diperoleh pembebanan arus lalu lintas pada jalan Sultan Hasanuddin sebesar 4,09\% dari total volume lalu lintas.

2. Pada ruas jalan Sultan Hasanuddin pada tahun 2019 derajat kejenuhannya adalah 0,31 dengan volume lalu lintas sebesar $1.740 \mathrm{SMP} / \mathrm{jam}$, dengan adanya RSUD Pangkep maka jalan Sultan Hasanuddin akan terbebani sebesar 9,36\% atau sebesar 162,81 SMP/ jam, dan pada tahun 2029 derajat kejenuhan sebesar 0,45 dengan volume lalu lintas sebesar 2.526,56 $\mathrm{SMP} /$ jam, hal ini menunjukkan kondisi yang masih cukup aman dengan masuk pada tingkat pelayanan $\mathrm{C}$ dengan karakter arus masih stabil namun kecepatan dan kemampuan bergerak semakin terbatas. Pada ruas jalan Mawar pada tahun 2019 derajat kejenuhannya adalah 0,36 dengan volume lalu lintas sebesar 709,5 SMP/ jam, dengan adanya RSUD Pangkep maka jalan Mawar akan terbebani sebesar 11,88 \% atau sebesar 84,33 SMP /jam, dan pada tahun 2029 derajat kejenuhan sebesar 0,53 dengan volume lalu lintas sebesar 1.030,21 SMP/jam. 
3 Berdasarkan hasil analisis tarikan lalu lintas dan kinerja ruas jalan pada Jalan Sultan Hasanuddin dan Jalan Mawar diperoleh bahwa arus lalu lintas jalan Sultan Hasanuddin dan jalan Mawar dari tahun ke tahun mengalami peningkatan sebesar 3,8\% pertahun sedangkan kapasitas ruas jalan tidak mengalami peningkatan, meskipun derajat kejenuhan yang diperoleh dari hasil perhitungan perbandingan antara arus lalu lintas dengan kapasitas jalan masih relatif aman yakni 0,45. Disamping itu berdasarkan hasil pengamatan dilapangan terhadap kondisi ruas jalan Mawar diperoleh bahwa banyaknya pedagang yang berjualan pada ruas jalan tersebut, kendaraan parkir pada bahu jalan dan adanya aktifitas orang yang lalu lalang.

Dengan kondisi tersebut perlu penanganan dampak lalu lintas sekaligus sebagai antisipasi terhadap hal-hal diluar perkiraan dari analisis yang digunakan antara lain:

a. Mengatur ruas jalan dengan cara memindahkan para pedagang yang ada dipinggir jalan serta membuat halte untuk tempat pemberhentian angkutan sehingga tidak mengganggu arus lalu lintas serta tidak menurunkan kapasitas jalan itu sendiri.

b. Menertibkan kendaraan dengan memberi tanda larangan parkir pada pinggir jalan masuk RSUD yang ada di jalan Mawar yang mana sangat berpengaruh terhadap kelancaran arus lalu lintas.

c. Membuat pengaturan lalu lintas untuk kendaraan yang masuk ataupun yang keluar dari RSUD dengan cara membuat traffic light atau dengan memberikan seorang petugas untuk membantu para pengunjung untuk masuk dan meninggalkan RSUD dengan aman tanpa mengganggu arus lalu lintas menerus.

\section{SARAN}

Berdasarkan hasil analisis dan pembahasan terhadap kondisi RSUD Pangkep maka disarankan :

1. Dalam perencanaan pengembangan suatu kawasan atau perencanaan tata ruang suatu wilayah hendaknya selalu terintegrasi dengan perencanaan jaringan transportasi kawasan tersebut, sehingga dampak lalu lintas yang timbul dapat diminimalkan dan memudahkan dalam penanganan.

2. Meningkatkan ketersediaan lahan parkir, dan manajemen parkir yang lebih teratur.

3. Mengatur ruas jalan dengan cara memindahkan para pedagang yang ada dipinggir jalan, menertibkan kendaraan dengan memberi tanda larangan parkir pada pinggir jalan masuk RSUD yang ada di jalan Mawar, serta membuat pengaturan lalu lintas untuk kendaraan yang masuk ataupun yang keluar dari RSUD.

\section{DAFTAR PUSTAKA}

Anonim, “Analisis Dampak Lalu Lintas”, Direktorat Jenderal Perhubungan Darat.

Anonim, 1996, "Perencanaan Transportasi", Lembaga Pengabdian Kepada Masyarakat, ITB Bekerja sama dengan KBK Rekayasa Transportasi, ITB,Bandung.

Anonim, 1997, "Manual Kapasitas Jalan Indonesia ( MKJI )", Direktorat Jenderal Bina Marga, Departemen Pekerjaan Umum,Jakarta.

Anonim, 1997,"Pemodelan Sistem Transportasi”, Lembaga Pengabdian Kepada Masyarakat, ITB, bekerja sama dengan KBK Rekayasa Transportasi, ITB,Bandung.

Arief SW, 2007, "Analisis Dampak Lalu Lintas Pada Pusat Perbelanjaan Yang Telah Beroperasi diTinjau Dari Tarikan Perjalanan", Tesis Magister, Teknik Transportasi, Program Studi Manajemen Rekayasa Infrastruktur, Universitas Diponegoro, Semarang.

Arikunto, S. 1988. Prosedur Penelitian. Rineka Cipta : Jakarta.

Aziz Zahwan, 2012, "Analisis Dampak Lalu Lintas Pengembangan RS. Telogorejo di Jl. KH.

Ahmad Dahlan Semarang", Teknik S i p i 1, Universitas Diponegoro, Semarang.

Badan Pusat Statistik Kabupaten Pangkajene dan Kepulauan. https://pangkepkab.bps.go.id, diakses

1 Pebruari 2019. 
Black, J.A. and Blunden,W.R., 1984, “The Land Use/Transport System”, Pergamos Press,Australia.

Cahyawati Yuly Fitriani Haryoputri. 2005 . "Analisis Tundaan Pada Ruas Jalan Majapahit Kota Semarang Dan Pengaruhnya Terhadap Konsumsi Bahan Bakar Minyak (BBM)”. Teknik Sipil Universitas Diponegoro Semarang.

C. Jotin Khisty \& B. Kent Lall. 2003. Dasar-dasar Rekayasa Transportasi jilid 1 edisi ketiga. Erlangga. Jakarta.

Della Giavanni. 2009 . "Analisis Pengaruh Aktivitas Di Pasar Tugu Bandar Lampung Terhadap Kinerja Lalu Lintas Di Jalan Hayam Wuruk Bandar Lampung”. Teknik Sipil Universitas Lampung.

Dikun, S. dan Arief, D., 1993,"Strategi Pemecahan Masalah Luas Bangunan dan Lalu Lintas", Bahan Seminar Dampak pemanfaatan Intensitas lahan gedung tinggi/Superblok di Jakarta terhadap lalu lintas disekitarnya, Universitas Taruma Negara bekerja sama dengan Pemerintah DKIJakarta.

Djamal, I dan Abimanyu, U, 1993, "Pengaruh Pemanfaatan Gedung Tinggi terhadap Dampak Lalu Lintas", Bahan Seminar Dampak pemanfaatan Intensitas lahan gedung tinggi/Superblok di Jakarta terhadap lalu lintas disekitarnya, Universitas Taruma Negara bekerja sama dengan Pemerintah DKIJakarta.

Gulo, W. 2002. Metode Penelitian. Jakarta: PT. Grasindo

Hendarto S.Lubis dkk. 2001. Dasar Dasar Transportasi. Bandung: ITB.

Herman Rauf, Theo K. Sendow, Audie L.E Rumayar.2015. Analisa Kinerja Lalu Lintas Akibat Besarnya Hambatan Samping Terhadap Kecepatan dengan Menggunakan Regresi Linier Berganda (Studi Kasus Ruas Jalan Dalam Kota Pada Segmen Jalan Lumimuut). Jurnal Sipil Statistik unsrat. Vol. 3 No. 10.

Hermon FT, 2016, "Analisis Dampak Lalu Lintas terhadap Pembangunan Hotel POP", Tesis Magister, Teknik Transportasi, Universitas Lampung, Bandar Lampung.

Hobbs, F.D, 1995. Perencanaan dan Teknik Lalu lintas, Fakultas Teknik, Universitas Gajah Mada, Yogyakarta.

Indriantoro, Supomo, 2002, Metodologi Penelitian Bisnis untuk Akuntansi dan Manajemen, Edisi Pertama, BPFE, Yogyakarta.

Jewel, L.N, dan Siegel Marc, 1998, Psikologi Industri/Organisasi Modern, Penerjemah, A Hadyana Pudjaatmaka dan Maetasari, Penerbit Archan, Jakarta.

Leksmono,S.P., 2007. Rekayasa Lalu Lintas. Indeks. Jakarta.

Mahmud . 2015 . "Pengaruh Aktivitas Samping terhadap Tingkat Pelayanan Jalan Kemakmuran Kabupaten Pangkep". Teknik Sipil Universitas Muslim Indonesia.

Mario Enrico, 2008 . "Studi Kinerja Jalan Akibat Variasi Hambatan Samping Di Jalan Jendral Sudirman Bandung”. Teknik Sipil Universitas Kristen Maranatha.

Miro. F, 2005, Perencanaan Transportasi. Erlangga, Jakarta.

Morlok, K. Edward. 1985. Pengantar Teknik dan Perencanaan Transportasi, Terjemahan Yani Sianipar, Erlangga, Jakarta.

Murwono, D, 2003, "Perencanaan Lingkungan Transportasi", Bahan Kuliah, Magister Sistem dan Teknik Transportasi, UGM,Yogyakarta.

Nasution, M.N, 2003 "Manajemen Transportasi”, Ghalia Indonesia.

Oglesty.C.H and Hicks.G..1993. Teknik Jalan Raya. terjemahan Erlangga. Jakarta.

Panahatan Marpaung. 2005 . "Analisis Hambatan Samping Sebagai Akibat Penggunaan Lahan Sekitarnya Terhadap Kinerja Jalan Juanda di Kota Bekasi”.Teknik Sipil Universitas Diponegoro Semarang.

Program Pascasarjana Universitas Muslim Indonesia Makassar, 2014. Pedoman Penulisan Tesis dan Disertasi. Makassar.

Pignataro, L. J. 1973. Traffic Engineering : Theory and Practice. Prentice-Hall Inc. New Jersey.

Salter, R.J, 1989, "Highway Traffic Analysis and Design", Second Edition, Mac Millan Education, Ltd,London.

Sergio LP, 2014, "Analisis Dampak Lalu Lintas Pada Pusat Perbelanjaan Timor Plaza Mall di Kota Dili", Tesis Magister, Teknik Transportasi, Universitas Atma Jaya, Yogyakarta 
Silvia Sukirman. Dasar-Dasar Perencanaan Geometrik Jalan. Nova. Bandung 1994

Sinulingga, Budi, D.1999. Pembangunan Kota, Tinjauan Regional dan Lokal. Pustaka Sinar Harapan, Jakarta

Siti Anugrah Mulya Putri Ofrial. 2013. "Analisis pengaruh hambatan samping terhadap kinerja lalu lintas di jalan Raden Inten Bandar Lampung”. Teknik Sipil Universitas Lampung.

Standly, 2004, "Analisis Dampak Lalu Lintas Pada Pusat Perbelanjaan Yang Telah Beroperasi", Tesis Magister, Teknik Transportasi, Program Studi Sistem dan Teknik Transportasi, UGM,Yogyakarta.

Sugiono, 2002, "Statistik Untuk Penelitian", Penerbit CV. Alfabeta, Bandung.

Supriharyono, 2000 "Inti Sari Materi Kuliah Metodologi Penelitian", Program Pascasarjana Magister Teknik Sipil Undip.

Syahidin, 2005, "Analisis Dampak Lalu - Lintas Akibat Pengoperasian Mal Jogjatronik Yogyakarta", Tesis Magister, Teknik Transportasi, Program Studi Sistem dan Teknik Transportasi, UGM,Yogyakarta

Tamin, Ofyar Z. 2000. Perencanaan dan Pemodelan Transportasi. Penerbit ITB, Bandung. 